\title{
Application of apricot stone waste from fruit processing industry in environmental cleanup: copper biosorption study
}

\author{
Tatjana Šoštarićc ${ }^{1 \star \star}$, Marija Petrović ${ }^{1}$, Jelena Milojković ${ }^{1}$, Časlav Lačnjevac ${ }^{2}$, Aleksandar Ćosovićc \\ Marija Stanojević ${ }^{1}$ and Mirjana Stojanović ${ }^{1}$ \\ 1 Institute for Technology of Nuclear and Other Mineral Raw Materials, Franchet d' Esperey 86, 11000 Belgrade, Serbia \\ 2 University of Belgrade, Faculty of Agriculture, Nemanjina 6, 11000 Belgrade, Serbia
}

Received 30 September 2014 - Accepted 20 May 2015

\begin{abstract}
Introduction. Apricots (Prunus armeniaca L.) have an important role in Serbia's fruit production. Average annual production of 25,035 $\mathrm{t}$ generates approximately 1,577 $\mathrm{t}$ apricot stone (AS) waste and most of it ends up in landfill sites. In order to minimize the environmental impact, an investigation of the possible use of AS was done by developing a biosorbent for wastewater treatment. Materials and methods. AS waste from the fruit processing industry was used to remove $\mathrm{Cu}(\mathrm{II})$ ions from water solution by batch adsorption techniques. This solid waste residue was characterized by FTIR, SEM and EDX. The effects of $\mathrm{pH}$, contact time, metal concentration and biosorbent dosage on the process of biosorption were studied. Results and discussion. Obtained FTIR results confirm that the uptake of $\mathrm{Cu}$ (II) ions from aqueous solution involves carboxylate moieties from lignin and fatty acids. Also, the presence of seeds in the AS blend significantly increased biosorption performance providing active sites important for the sorption process. The ion exchange mechanism was also confirmed. The best fitting adsorption model is the Langmuir model and the maximum biosorption capacity $\left(\mathrm{q}_{\max }\right)$ is $4.45 \mathrm{mg} \mathrm{L}^{-1}$ at $\mathrm{pH} 5.0$. Biosorption of the $\mathrm{Cu}$ (II) ions follows a pseudo secondorder kinetic model. According to thermodynamic parameters the biosorption process is endothermic and spontaneous. Conclusion. Numerous biosorbents were investigated for biosorption of $\mathrm{Cu}$ (II) ions from aqueous solution, but no report on application of untreated AS waste has been found in literature. This preliminary study confirmed that this material can successfully and rapidly remove dissolved copper ions from dilute solutions.
\end{abstract}

Keywords: Serbia / apricot / Prunus armeniaca / waste management / biosorption / copper ions

\begin{abstract}
Résumé - Application des déchets de noyaux d'abricot issus de l'industrie agro-alimentaire à la dépollution : étude de la biosorption du cuivre. Introduction. L'abricot (Prunus armeniaca L.) tient une place importante dans l'économie de la Serbie. La production annuelle moyenne de 25035 t génère environ 1577 t de déchets de noyaux d'abricots (AS) dont la plus grande partie se retrouve dans des sites d'enfouissement. Afin de minimiser l'impact environnemental de ces déchets, une l'utilisation possible des AS a été envisagée, visant à développer un biosorbant pour le traitement des eaux usées. Matériel et méthodes. Les déchets AS provenant de l'industrie agro-alimentaire ont été utilisés pour éliminer les ions $\mathrm{Cu}$ (II) de solutions aqueuses par des techniques d'adsorption par lots. Le résidu des déchets solides a été caractérisé par spectroscopie infrarouge à transformation de Fourier (FTIR), microscopie électronique $(\mathrm{SEM})$ et radioscopie à dispersion d'énergie (EDX). Les effets du $\mathrm{pH}$, du temps de contact, de la concentration et du dosage du métal sur le biosorbant ont été étudiés au cours du processus de biosorption. Résultats et discussion. Les résultats obtenus par FTIR confirment que l'absorption des ions $\mathrm{Cu}$ (II) de la solution aqueuse met en jeu des groupements carboxylate issus de la lignine et des acides gras des noyaux d'abricot. En outre, la présence des graines dans mélange AS a augmenté de manière significative les performances de biosorption, en apportant des sites actifs sur le processus de sorption. Le mécanisme d'échange d'ions a également été confirmé. Le meilleur modèle proposé est le modèle d'adsorption de Langmuir dont la capacité de biosorption maximale $\left(q_{\max }\right)$ est de $4,45 \mathrm{mg} \mathrm{L}^{-1}$ à $\mathrm{pH} 5,0$. La biosorption des ions $\mathrm{Cu}$ (II) suit un pseudo-modèle cinétique de second ordre. Selon les paramètres thermodynamiques, le processus de biosorption est endothermique et spontané. Conclusion. De nombreux biosorbants ont été étudiés pour la biosorption des ions $\mathrm{Cu}$ (II) dans une solution aqueuse, mais aucune application au traitement des déchets AS n'avait été rapportée dans la littérature. Cette étude préliminaire confirme que ce matériau peut rapidement et effectivement éliminer les ions cuivre dissous à partir de solutions diluées.
\end{abstract}

Mots clés : Serbie / abricot / Prunus armeniaca / traitement des déchets / biosorption / ions métallique / cuivre

^ Corresponding author: t.sostaric@itnms.ac.rs 


\section{Introduction}

The waste generated in fruit processing industries can be in liquid, solid or gas state and its constitution is correlated to the material used in the technological process. Wastewater from these industries are characterized by high biodegradable effluents, large seasonal volumes and variation in effluent volume. Wastewater and solid state waste are prone to putrefaction and cannot be stored for long periods of time. Air pollution comes from the smell from the technological process and solid waste depots. If waste is not treated properly, it has a great potential for pollution.

In order to minimize solid waste it is possible to extract some valuable compounds but often vast quantities of lignocellulose fraction stay unused although it can be used for the production of bioethanol or as cattle feed [1]. Also the lignocellulose material can be used as adsorbent for the removal of pollutants from the wastewater either in its native form [2,3], treated form [4-7], or for production of active carbon $[8,9]$. Although there are several conventional treatments of wastewater, researchers are focused on the development of biotechnological solutions that are environmental friendly [10]. In this framework, utilization of ligno-cellulosic biomass as adsorbent for metal removal from wastewater is recommended since it is abundant and low cost [5,11-13].

In order to eliminate heavy metals from wastewater a wide range of solid waste from fruit processing industry has been examined as cheap and non-pollutant materials which are able to reduce the costs and maximize the efficiency [10]. Wastes such as grape stalk waste [14], banana and orange peels [15], apple residues [16], peach shells [17], grapefruit peel [18], pomegranate peel [19], citrus peels [20] previously were studied for the removal of metal ions.

Apricot (Prunus armeniaca L.) has an important role in Serbia fruit production. Average annual production of 25,035 t generates approximately $1,577 \mathrm{t}$ apricot stone (AS) waste [21]. Apricot stone shells can be used for the production of active carbon [9,22-24] while the seeds can be used in the cosmetic and food industry [25]. At present there is no strategic management of this kind of waste in Serbia and most of it is taken to the landfill sites.

This paper deals with investigation of the possible use of solid waste residue (AS) from the juice factory "Vino Župa" Aleksandrovac in Serbia, in order to develop and recover a usable product. According to the data from this factory, 500 to $1,000 \mathrm{t}$ AS waste are generated per month during the summer season.

\section{Materials and methods}

\subsection{Biosorbent preparation}

The apricot stone wastes were obtained from Juice Factory "Vino Župa" Aleksandrovac, Serbia. Apricots that are used in the production process belong to a variety locally known as "Novosadska rodna" which has sweet seeds that do not contain amygdalin [26].
Apricot stones (AS) were air-dried, milled (KHD Humbolt Wedag AG) and $<1 \mathrm{~mm}$ fraction was chosen for the biosorption tests. Samples were washed with deionized water to remove impurities, dried at $60{ }^{\circ} \mathrm{C}$ and stored in dry plastic containers for further analyses. Certain amounts of AS were separated into: shells (SH) and seeds (SE). In this variety of apricot $20 \%$ of the stone mass are made of the seed.

\subsection{Characterization of biomaterials}

In order to determine the complex nature of biosorbent a Fourier Transform Infrared (FTIR) spectroscopy analyses of apricot shells (SH), seeds (SE) and mixture of both (AS) have been included. The characterization was carried out in order to determine chemical functional groups on their surface available for binding $\mathrm{Cu}$ (II) ions. Also the FTIR spectrum of waste $\mathrm{AS}$ was taken after $\mathrm{Cu}(\mathrm{II})$ ion removal (ASCu) to identify functional groups which are involved in biosorption process. The FTIR spectra were taken using Thermo Nicolet 6700 FTIR working in attenuated total reflectance mode (FTIRATR), connected with the OMNIC Software (Thermo Nicolet).

Scanning Electron Microscopy (SEM) and Energy Dispersive X-Ray analysis (EDX) were used to determine surface morphology of AS before and after the biosorption process. Before analysis all samples were coated with gold. SEM-EDX analysis was performed using a JEOL JSM-6610 LV SEM model.

Nitrogen adsorption-desorption isotherms were determined on a Sorptomatic 1990 Thermo Finnigan automatic system using nitrogen physisorption at $-196{ }^{\circ} \mathrm{C}$. Before the measurement the samples were outgassed at $40{ }^{\circ} \mathrm{C}$ for $12 \mathrm{~h}$. The specific surface area of the samples was calculated from the nitrogen adsorption-desorption isotherms according to the Brunauer, Emmett and Teller (BET) method [27].

In order to determine the content of crude cellulose, lignin acid detergent fibres, (ADF) and neutral detergent fibres (NDF) a fibre analyzer (A2000, ANKOM, Macedon, NY, USA) was used. 'Acid detergent fibres' (ADF) refers to the insoluble fibres within a plant cell wall namely cellulose and lignin, whereas, 'neutral detergent fibres' refers to the total plant cell wall material and its value comprised of ADF plus insoluble hemicelluloses [28]. Nitrogen free extracts (NFE) represent soluble carbohydrates such as starch and sugars. Crude fat, dry matter, ash and moisture content were determined gravimetrically after extraction and crude protein were determined volumetrically.

\subsection{Point of zero charge}

The point of zero charge $\left(\mathrm{pH}_{\mathrm{pzc}}\right)$ was determined using 0.1 , 0.01 and $0.001 \mathrm{~mol} \mathrm{~L}^{-1} \mathrm{KNO}_{3}$ (p.a. Aldrich). The initial $\mathrm{pH}$ $\left(\mathrm{pH}_{\mathrm{i}}\right)$ values of the solutions were adjusted with $0.1 \mathrm{~mol} \mathrm{~L}^{-1}$ $\mathrm{HNO}_{3}$ and $0.1 \mathrm{~mol} \mathrm{~L}{ }^{-1} \mathrm{KOH}$. Experiments were conducted in $100 \mathrm{~mL}$ flasks with mixture of $50 \mathrm{~mL}$ of the solution at varies initial $\mathrm{pH}$ values and $0.1 \mathrm{~g}$ biosorbent and then they were shaken for $24 \mathrm{~h}$. After filtration, in each supernatant $\mathrm{pH}$ final $\left(\mathrm{pH}_{\mathrm{f}}\right)$ was measured using $\mathrm{pH}$ meter (Sension MM340). The 
plateau from the curve $\mathrm{pH}_{\mathrm{f}}=\mathrm{f}\left(\mathrm{pH}_{\mathrm{i}}\right)$, was determined as the value of $\mathrm{pH}_{\mathrm{pzc}}$ [29].

\subsection{Adsorption equilibrium studies}

Stock solutions were prepared by dissolving precise amount of $\mathrm{Cu}\left(\mathrm{NO}_{3}\right)_{2} \times 3 \mathrm{H}_{2} \mathrm{O}$ (p.a. grade) in deionized water. Copper solutions with different concentrations were prepared by dilution of the stock solution. Value of $\mathrm{pH}$ was adjusted to 5.0 with $0.1 \mathrm{~mol} \mathrm{~L}^{-1} \mathrm{HNO}_{3}$ and $0.1 \mathrm{~mol} \mathrm{~L}^{-1} \mathrm{KOH}$ solutions. No further adjustment of $\mathrm{pH}$ value was done during experiments.

The batch experiments were conducted in $100 \mathrm{~mL}$ Erlenmeyer flasks with a mixture of a metal solution and a various amount of biosorbent, which were shaken at $250 \mathrm{rpm}$ for 120 minutes at $303 \mathrm{~K}$. Afterward, the mixture was filtrated and the concentration of $\mathrm{Ca}^{2+}, \mathrm{Mg}^{2+}, \mathrm{Na}^{+}, \mathrm{K}^{+}$and $\mathrm{Cu}^{2+}$ were analysed by Atomic Absorption Spectrometer (PerkinElmer, model AAnalyst 300). All experiments were performed in duplicate. A sorption equilibrium study was carried out with different solution concentrations (from 6 to $150 \mathrm{mg} \mathrm{L}^{-1}$ ) at pH 5.0 using $6 \mathrm{~g} \mathrm{~L}^{-1}$ of biosorbent. The amount of $\mathrm{Cu}(\mathrm{II})$ ions adsorbed by the biosorbents was obtained by the following equation:

$$
q=\frac{\left(C_{i}-C_{e q}\right) V}{m}
$$

where $C_{i}$ and $C_{e q}\left(\mathrm{mg} \mathrm{L}^{-1}\right)$ are the initial and the equilibrium metal ion concentration, respectively, $m(\mathrm{~g})$ is the mass of biosorbent and $V(\mathrm{~L})$ is the volume of the solution. The removal efficiency of $\mathrm{Cu}(\mathrm{II})$ was calculated using the following equation:

$$
R=\frac{\left(C_{i}-C_{e q}\right) 100}{C_{i}}
$$

where $C_{\mathrm{i}}$ and $C_{e q}\left(\mathrm{mg} \mathrm{L}^{-1}\right)$ are the initial and final equilibrium $\mathrm{Cu}(\mathrm{II})$ ion concentration, respectively.

\subsection{Metal desorption study}

Testing AS desorption efficiency was carried out with various concentrations of $\mathrm{HCl}$ solution (at $0.1,0.5$ and $1 \mathrm{~mol} \mathrm{~L}^{-1}$ ). The desorption of $\mathrm{Cu}(\mathrm{II})$ ions was found to be most effective by using $0.1 \mathrm{~mol} \mathrm{~L}^{-1} \mathrm{HCl}$ solution.

Adsorption-desorption experiments were carried out in five cycles using $0.1 \mathrm{~mol} \mathrm{~L}^{-1} \mathrm{HCl}$ and same biosorbent. Biosorption experiments were done at optimum parameters such as: $\mathrm{pH}=5.0$, biomass concentration of $6 \mathrm{~g} \mathrm{~L}^{-1}$, contact time of $120 \mathrm{~min}$ and initial $\mathrm{Cu}$ (II) ion concentration at $60 \mathrm{mg} \mathrm{L}^{-1}$. Afterwards the samples were centrifuged and metal content was analysed in supernatant. In desorption experiments metal loaded biomass was treated with $50 \mathrm{~mL}$ of $0.1 \mathrm{~mol} \mathrm{~L}^{-1} \mathrm{HCl}$ solution for $120 \mathrm{~min}$. The samples were then centrifuged and supernatants were analysed for metal content.
Table I. Chemical composition of apricot stones waste. Values are expressed in dry matter. Mean of two repetitions \pm standard deviation.

\begin{tabular}{lc}
\hline Component & Content (in \% DW) \\
\hline Dry matter & $93.43 \pm 1.78$ \\
Moisture & $6.57 \pm 0.12$ \\
Crude protein & $3.57 \pm 0.15$ \\
Crude fat & $5.52 \pm 0.33$ \\
Crude cellulose & $38.81 \pm 1.79$ \\
Ash & $1.08 \pm 0.03$ \\
NFE $^{\mathrm{a}}$ & $55.55 \pm 5.10$ \\
NDF $^{\mathrm{b}}$ & $79.05 \pm 4.72$ \\
$\mathrm{ADF}^{\mathrm{c}}$ & $61.22 \pm 4.42$ \\
Lignin $_{\text {Hemicellulose }}$ & $23.04 \pm 1.97$ \\
\hline
\end{tabular}

${ }^{a}$ NFE - Nitrogen free extract; ${ }^{b}$ NDF - Neutral detergent fiber; ${ }^{c}$ ADF - Acid detergent fiber.

\subsection{Statistical analysis}

All data represents the mean of experiments performed in duplicate. Average values \pm SD (error bars) are presented in all graphs. The correlation coefficient $\left(R^{2}\right)$ values of Langmuir and Freundlich isotherm models and pseudo first and pseudo second order kinetic models were determined using statistical function of Microsoft Origin 7.0.

In kinetic study, both kinetic models were verified using the sum of squared errors (SSE). The SSE value was calculated using

$$
S S E=\sum \frac{\left(q_{\exp }-q_{c a l}\right)^{2}}{q_{\exp }^{2}}
$$

where $q_{\text {exp }}$ and $q_{c a l}$ are the experimental biosorption capacities $\left(\mathrm{mg} \mathrm{g}^{-1}\right)$ at time $t$ and the corresponding values that are gained from kinetic models [30]. SSE values for both kinetic models are summarized in table III.

\section{Results and discussion}

\subsection{Characterization of apricot stone waste}

The chemical composition of AS waste clearly indicated (table I) that AS are ligno-cellulosic materials, which mainly contains cellulose, hemicellulose and lignin. Crude protein and fat mainly come from seeds that are rich in fat and crude protein. Sweet apricot seeds contain $53.3 \%$ oil (especially unsaturated acids such as oleic and linoleic acid that make up to $93 \%$ of total fatty acids), $25.4 \%$ protein, $6.5 \%$ sugars, $7.5 \% \mathrm{NDF}$, $5 \%$ ADF and $2.6 \%$ ash [26].

BET surface area of AS waste is $1.3 \mathrm{~m}^{2} \mathrm{~g}^{-1}$, which is in accordance with previously published data for similar lignocellulosic biomaterials [31]. However, SEM micrographs (figure 1) showed that AS waste is porous material which is easily accessible for penetration of $\mathrm{Cu}$ (II) ions solution to the active sites. It is known that the adsorption of any heavy metal with smaller ionic radius is greater than that with a larger ionic radius because it has more accessibility to the surface and pores 

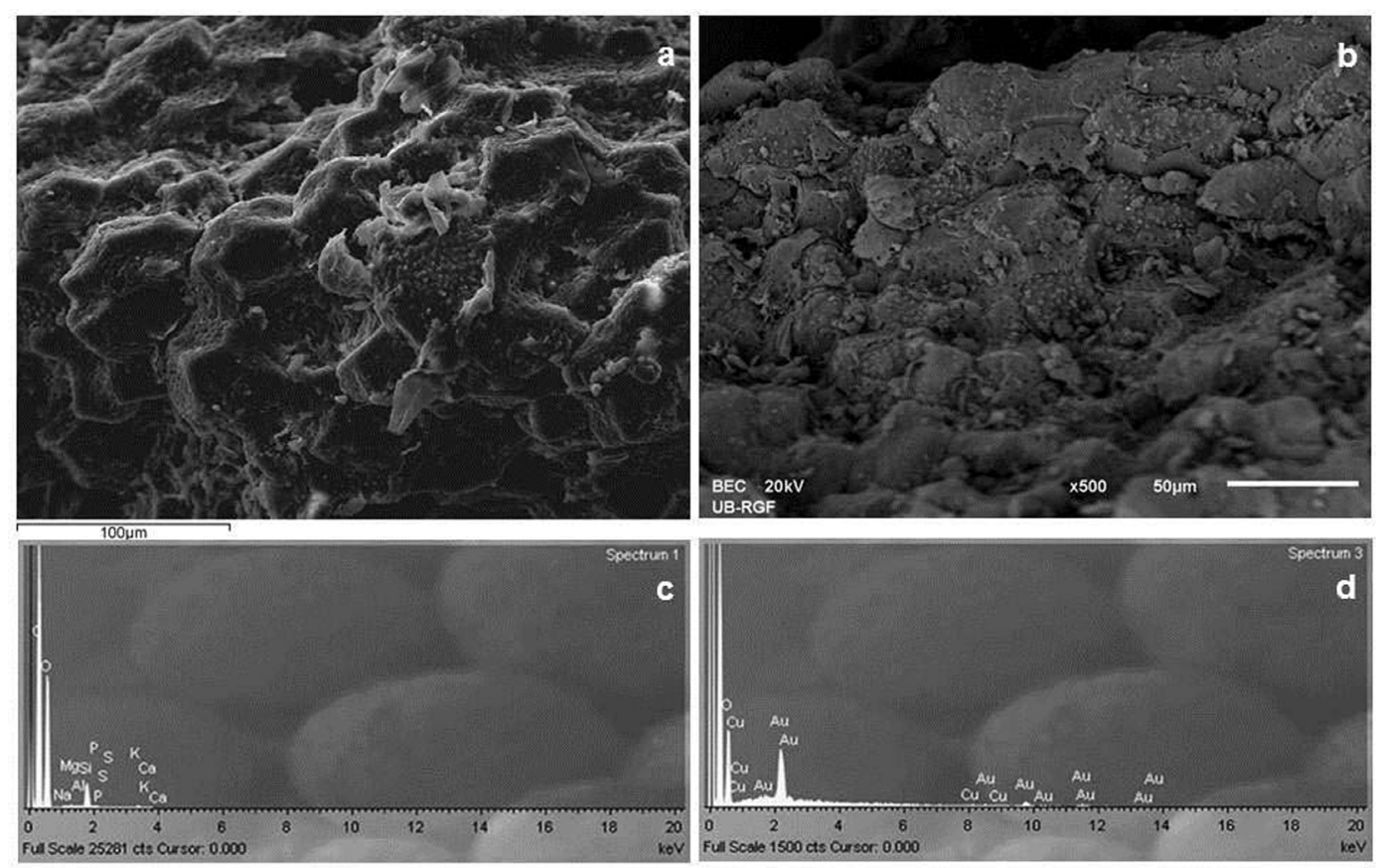

Figure 1. SEM micrographs of apricot stone (AS) waste (a): before, and (b): after biosorption; and EDX spectrums of AS waste (c): before, and (d): after biosorption of $\mathrm{Cu}(\mathrm{II})$ ions.

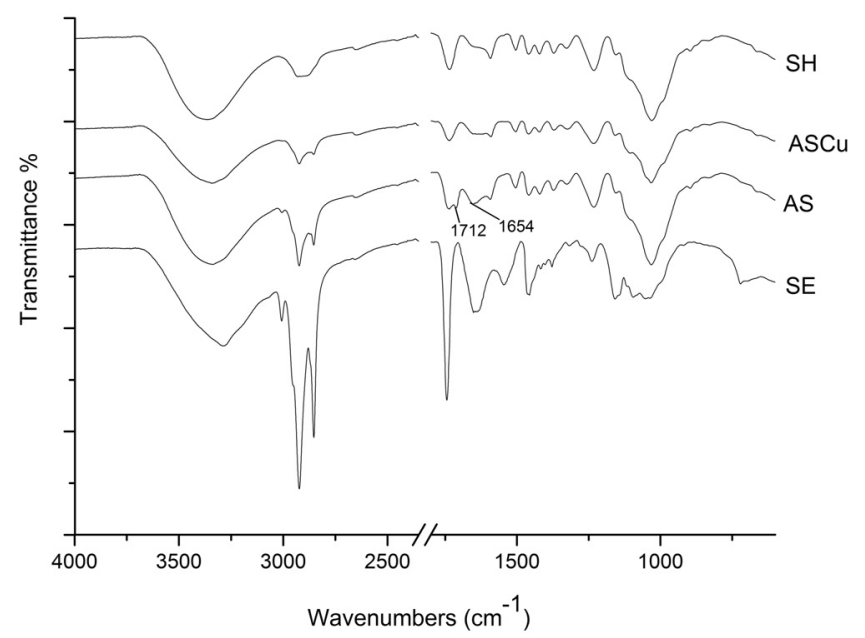

Figure 2. The FTIR spectra of: shells (SH), seeds (SE) and apricot stones (AS): before, and (ASCu): after sorption of $\mathrm{Cu}(\mathrm{II})$ ions.

of the adsorbent than the bigger ones [32]. The ionic radius of the $\mathrm{Cu}$ (II) is $0.73 \mathrm{~A}^{\circ}$, which is smaller than the radius of some other heavy metals such as $\mathrm{Pb}(\mathrm{II}), \mathrm{Cd}(\mathrm{II}), \mathrm{Zn}(\mathrm{II})$.

The EDX results of AS waste after biosorption showed the presence of $\mathrm{Cu}(\mathrm{II})$ ions providing the evidence for the sorption of copper onto biosorbent. Some ions which are capable of ion-exchange, completely vanished after biosorption of $\mathrm{Cu}(\mathrm{II})$ ions onto AS waste (figure 1).

In order to present the complex nature of the AS waste, FTIR spectra of both parts (shells and seeds) were investigated. The results revealed significant differences between these samples (figure 2). All samples have similar broadband in the region between 3100 and $3600 \mathrm{~cm}^{-1}$ that corresponds to $-\mathrm{OH}$ stretching vibrations. Detected - $\mathrm{OH}$ groups probably originate from alcohols, phenols and carboxylic acids [33]. Differences between seeds (SE) and shells (SH) spectra are noticeable.

In SE spectrum a small peak observed at $3,007 \mathrm{~cm}^{-1}$ is assigned to $\mathrm{C}=\mathrm{C}-\mathrm{H}$ stretching vibration peak in fatty acids [34]. Intense peaks at $2,923 \mathrm{~cm}^{-1}$ and $2,853 \mathrm{~cm}^{-1}$ can be attributed to asymmetric and symmetric $-\mathrm{CH}_{2}$ and $-\mathrm{CH}_{3}$ stretching, respectively arising from the aliphatic chains of organic acids [35]. This is in accordance with a fact that SE has high content of fatty acids [26]. There are few more distinctive bands at FTIR spectrum of SE: the very sharp peak at $1,744 \mathrm{~cm}^{-1}$ is assigned to $-\mathrm{C}=\mathrm{O}$ stretching vibration in carbonyl compounds which may be due to high content of polyphenols; the intense band at $1,636 \mathrm{~cm}^{-1}$ is assigned to $\mathrm{C}-\mathrm{C}$ stretching with aromatic ring due to presence of phenols [36]; and the peak at $1,456 \mathrm{~cm}^{-1}$ is due to carboxylic $\mathrm{C}-\mathrm{O}$ band of polyphenols [37].

In the FTIR spectrum of SH peak at $1,732 \mathrm{~cm}^{-1}$ is assigned to aromatic carbonyl or carboxyl $\mathrm{C}=\mathrm{O}$ stretching of carboxylic acids or their esters [36]. Furthermore, the peaks appearing at $1,593 \mathrm{~cm}^{-1}, 1,505 \mathrm{~cm}^{1}$ and $1,456 \mathrm{~cm}^{-1}$ are assigned to the $\mathrm{C}=\mathrm{C}$ stretching in aromatic ring $[36,38,39]$. Absorbance peaks at $1,422 \mathrm{~cm}^{-1}$ and $1,372 \mathrm{~cm}^{-1}$ observed in $\mathrm{SH}$ spectrum can be attributed to the $\mathrm{C}-\mathrm{H}$ asymmetric and symmetric deformations, respectively [40].

The strong and intense band at $1,030 \mathrm{~cm}^{-1}$ could be assigned to the stretching vibration of $\mathrm{C}-\mathrm{OH}$ of alcoholic groups and carboxylic acids [36] and confirms the lignin structure of the SH [41]. The peaks at $896 \mathrm{~cm}^{-1}$ and $826 \mathrm{~cm}^{-1}$ can be assigned to $\mathrm{C}-\mathrm{H}_{\mathrm{n}}$ aliphatic or aromatic bonds [35]. 


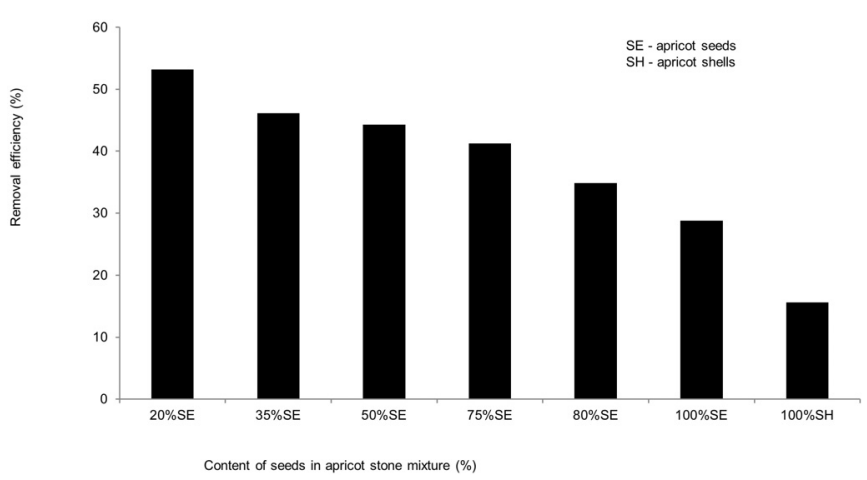

Figure 3. Synergistic effect of seeds (SE) and shells (SH) on biosorption efficiency: $m / V=10 \mathrm{~g} \mathrm{~L}^{-1}, C_{i}=60 \mathrm{mg} \mathrm{L}^{-1}, t=120 \mathrm{~min}$.

The FTIR spectra of AS before and after biosorption of $\mathrm{Cu}$ (II) ions were studied, too. The peaks at $1,712 \mathrm{~cm}^{-1}$ and at $1,654 \mathrm{~cm}^{-1}$ from spectrum of untreated AS are disappeared after biosorption. Bands around 1,650 and $1,750 \mathrm{~cm}^{-1}$ are assigned to free and esterified carboxyl groups which indicate that these groups were involved in copper biosorption [36]. The peak at $1,326 \mathrm{~cm}^{-1}$ in AS spectrum before biosorption decreased to $1,323 \mathrm{~cm}^{-1}$ (the bending vibration of $\mathrm{OH}$ ), indicating that bonds in aromatic rings of lignin contributed to biosorption [42].

The obtained FTIR results confirmed that the biosorption of $\mathrm{Cu}$ (II) ions from aqueous solution involved carboxylate moieties from lignin and fatty acids. This is in accordance with the presence of apricot seeds (20\% of the stone mass) in AS blend, which significantly affected adsorption performance (figure 3), providing active sites important for the biosorption process.

\subsection{Effect of the initial solution $\mathrm{pH}$ and $\mathrm{pH}_{\mathrm{pzc}}$}

Previous studies have shown that the $\mathrm{pH}$ of the solution is one of the most significant parameters influencing biosorption of heavy metal ions $[17,43,44]$. It affects both the chemical properties of the solution and the biosorbent surface charge.

The biosorption efficiency increased with increasing $\mathrm{pH}$ values (figure 4). When $\mathrm{pH}$ value of solution was low, the concentration of $\mathrm{H}^{+}$ions was high, resulting in less active sites for $\mathrm{Cu}$ (II) removal. This is because of the strong competition between hydrogen and $\mathrm{Cu}(\mathrm{II})$ ions for the active sites in the biosorbent [45]. However the increase in solution $\mathrm{pH}$ leads to more active sites on the surface of the biosorbent with negative charges which become available for $\mathrm{Cu}$ (II) resulting in bigger biosorption efficiency [46].

The value of sorbent $\mathrm{pH}_{\mathrm{pzc}}$ gives information about possible attraction and repulsion between sorbent and sorbate (figure 4). The solid surface is positively charged when solution $\mathrm{pH}$ is lower than $\mathrm{pH}_{\mathrm{pzc}}$ and could interact with anions, while sorbent surface is negatively charged when solution pHs is higher than $\mathrm{pH}_{\mathrm{pzc}}$ and could interact with metal cations [36]. Considering the point of zero charge value $(=4.50)$ and the fact that almost all copper ions are present in the ionic form of $\mathrm{Cu}$ (II) at $\mathrm{pH}<6.0$, all experiments were carried out at $\mathrm{pH} 5.0$.
Knowledge of sorbent $\mathrm{pH}_{\mathrm{pzc}}$ value indicates that electrostatic force is one of the mechanisms in the biosorption process [47]. However at $\mathrm{pH} 4.0\left(\mathrm{pH}<\mathrm{pH}_{\mathrm{pzc}}\right)$ biosorption yield reached its maximum indicating that electrostatic force mechanism was not the only mechanism that affected the biosorption process.

\subsection{Effect of biosorbent dosage and initial copper concentration}

The effects of biosorbent dosage and initial concentration of $\mathrm{Cu}(\mathrm{II})$ ions was investigated by varying the amount and concentration of biosorbent of metal in solution, respectively (figure 5). The highest biosorption capacity was achieved with biosorbent dosage of $6 \mathrm{~g} \mathrm{~L}^{-1}$. The decrease of biosorption capacity with increasing the biosorbent dosage may be attributed to overlapping or aggregation of biosorption sites [48]. In accordance with expectations biosorption capacity increased by increasing the initial metal concentration from 6 to $140 \mathrm{mg} \mathrm{L}^{-1}$. The highest biosorption capacity was at the initial concentration of $60 \mathrm{mg} \mathrm{L}^{-1}$ for a biosorbent dosage of $6 \mathrm{~g} \mathrm{~L}^{-1}$.

\subsection{Ion-exchange mechanism}

The involvement of ion-exchange mechanism during the biosorption process was studied by following the release of cations $\left(\mathrm{Ca}^{2+}, \mathrm{Mg}^{2+}, \mathrm{Na}^{+}, \mathrm{K}^{+}\right.$and $\left.\mathrm{H}^{+}\right)$from biosorbent after biosorption of $\mathrm{Cu}$ (II) ions from aqueous solution. The release of cations from biosorbent after washing with deionized water was considered as control. The net release of cations has been calculated by subtracting those two amounts of cations. The ratio of copper bound to cation released was calculated as:

$$
R_{\frac{b}{r}}=\frac{C u^{2+}}{C a^{2+}+M g^{2+}+\frac{N a^{+}}{2}+\frac{K^{+}}{2}+\frac{H^{+}}{2}}
$$

where $R_{b / r}$ is the ratio of the adsorbed and released cations from the AS and $\mathrm{Cu}^{2+}, \mathrm{Ca}^{2+}, \mathrm{Mg}^{2+}, \mathrm{Na}^{+}, \mathrm{K}^{+}$and $\mathrm{H}^{+}\left(\right.$meq g ${ }^{-1}$ ) is amount of $\mathrm{Cu}^{2+}$ adsorbed and $\mathrm{Ca}^{2+}, \mathrm{Mg}^{2+}, \mathrm{Na}^{+}, \mathrm{K}^{+}$and $\mathrm{H}^{+}$ released from the AS, respectively.

Results presented in table II showed a significant release of cations from AS waste after process of biosorption, which may indicate the displacement of these cations by $\mathrm{Cu}(\mathrm{II})$ ions. According to some authors there is a strong interaction between ligno-cellulosic biosorbents and metal bearing solution, confirming the substitution of alkali-earth rather than alkali metals from biosorbent by protons and heavy metal ions $[14,49,50]$.

Indication of ion exchange mechanism is when $R_{b / r}$ (ratio between bonded and realised ions) value is 1 . Since the $R_{b / r}$ is close to 1, ion exchange mechanism might be an important mechanism in biosorption of $\mathrm{Cu}(\mathrm{II})$ ions by $\mathrm{AS}$ waste, which is in correlation with EDX results (figure 1).

\subsection{Effect of contact time}

Within 10 min, biosorption equilibrium was achieved (figure 6 ) and after this point the curve turned flat. Similar results 

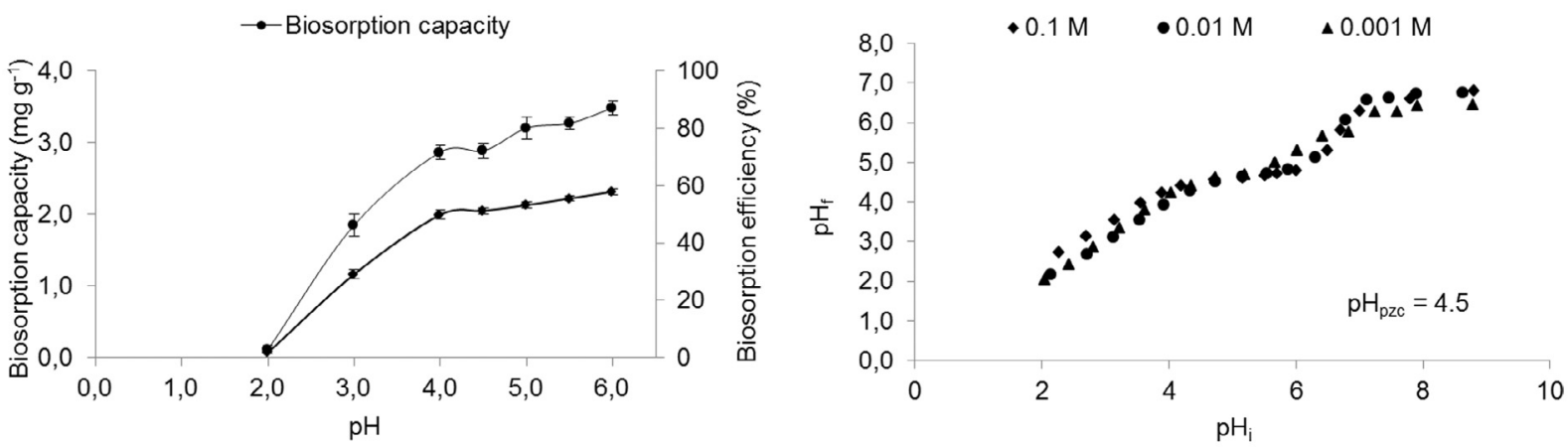

Figure 4. Effect of $\mathrm{pH}$ on the biosorption of $\mathrm{Cu}(\mathrm{II})$ ions by AS: $C_{i}=60 \mathrm{mg} \mathrm{L}^{-1}, m / V=10 \mathrm{~g} \mathrm{~L}^{-1}, t=120$ min, and determination of the point of zero charge.

Table II. Release of $\mathrm{K}^{+}, \mathrm{Mg}^{2+}, \mathrm{Na}^{+}, \mathrm{Ca}^{2+}$ and $\mathrm{H}^{+}$due to biosorption of $\mathrm{Cu}^{2+}$ by apricot stones waste.

\begin{tabular}{|c|c|c|c|c|c|c|c|}
\hline \multicolumn{2}{|c|}{ Total metal bound (meq $\mathrm{g}^{-1}$ ) } & \multicolumn{5}{|c|}{ Net amount of cation released (meq g $\left.{ }^{-1}\right)$} & \multirow[t]{2}{*}{$\mathrm{R}_{\mathrm{b} / \mathrm{r}}$} \\
\hline & $\mathrm{Cu}^{2+}$ & $\mathrm{K}^{+}$ & $\mathrm{Na}^{+}$ & $\mathrm{Mg}^{2+}$ & $\mathrm{Ca}^{2+}$ & $\mathrm{H}^{+}$ & \\
\hline After biosorption & 0.1265 & 0.0800 & 0.0016 & 0.0610 & 0.0372 & 0.0193 & 0.9 \\
\hline Control & & 0.0484 & 0.0016 & 0.0050 & 0.0042 & -0.0047 & \\
\hline Difference & & 0.0316 & 0.00 & 0.0560 & 0.0330 & 0.0240 & \\
\hline
\end{tabular}

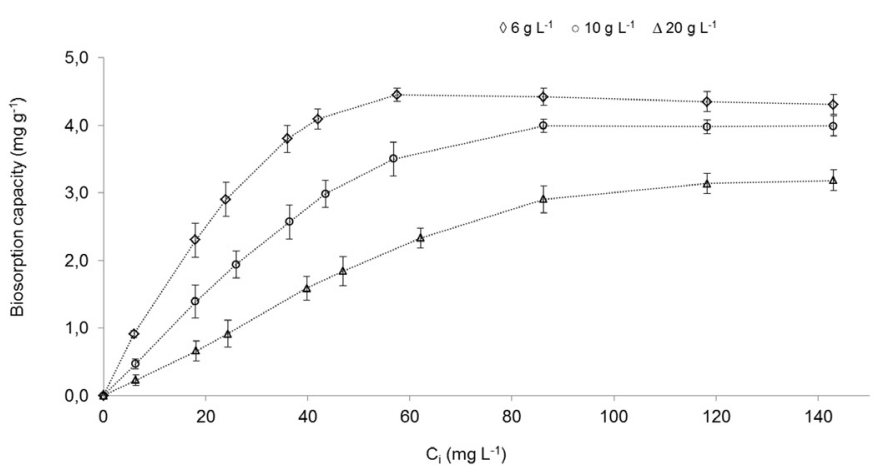

Figure 5. Effect of biosorbent dosage on the biosorption of $\mathrm{Cu}(\mathrm{II})$ ions by AS: $\mathrm{pH}=5.0, t=120 \mathrm{~min}$.

were observed in case of changes in $\mathrm{pH}$ value. During the process of biosorption the initial value of $\mathrm{pH}$ can change, enabling micro-precipitation on the surface of biosorbent [50]. Significant changes in final $\mathrm{pH}$ value were not detected after $120 \mathrm{~min}$. All further experiments were performed in the time period of $120 \mathrm{~min}$ to ensure the biosorption equilibrium.

\subsection{Sorption isotherms}

The adsorption isotherm illustrates the relationship among the quantity of adsorbate uptaken by the biosorbent and the adsorbate concentration remaining in solution [51]. In order to analyze the experimental data obtained for the biosorption of $\mathrm{Cu}$ (II) ions, two models were considered: Langmuir and Freundlich.

Langmuir isotherm assumes that adsorption occurs in a monolayer or the adsorption may only occur at a fixed number of well-defined sites on the surface on which all adsorption

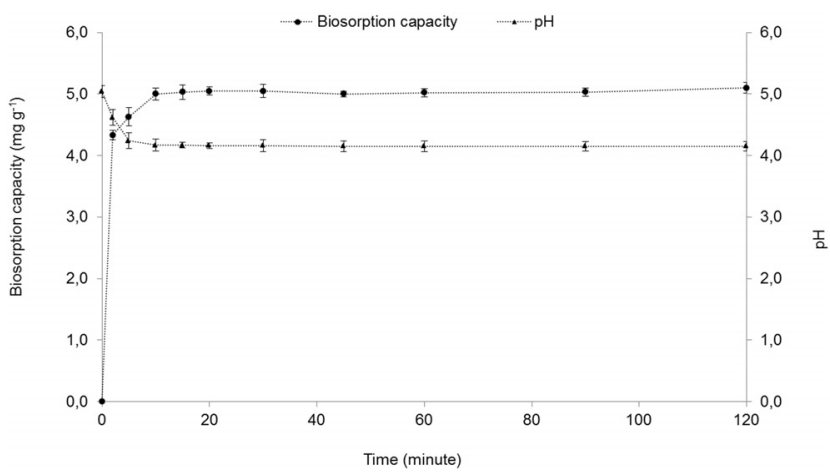

Figure 6. Changes of biosorption capacity and $\mathrm{pH}$ value during contact time: $m / V=6 \mathrm{~g} \mathrm{~L}^{-1}, C_{i}=60 \mathrm{mg} \mathrm{L}^{-1}, \mathrm{pH}=5.0 t=120 \mathrm{~min}$.

sites are energetically equivalent [45]. This isotherm model is defined by the following equation:

$$
q=\frac{q_{m} K_{L} C}{1+K_{L} C}
$$

Biosorption capacity - $q\left(\mathrm{mg} \mathrm{g}^{-1}\right)$ is the amount of metal ions adsorbed per mass of adsorbent, $C\left(\mathrm{mg} \mathrm{L}^{-1}\right)$ is the equilibrium concentration, $q_{m}\left(\mathrm{mg} \mathrm{g}^{-1}\right)$ is the maximum adsorption capacity of the biosorbent required to form a monolayer on the surface of biosorbent, $K_{L}\left(\mathrm{~L} \mathrm{mg}^{-1}\right)$ is the Langmuir constants. Separation factor $\left(R_{L}\right)$ is a dimensionless constant, which indicates the nature of shape of the Langmuir isotherm accordingly: $R_{L}>1$ (unfavourable adsorption); $0<R_{L}<1$ (favourable adsorption); $R_{L}=0$ (irreversible adsorption); $R_{L}=1$ (linear adsorption) [52]. It is expressed with the following equation:

$$
R_{L}=\frac{1}{1+\left(K_{L}+C_{i}\right)}
$$


Table III. Comparison between pseudo-first order and pseudo-second order kinetic models, and values of thermodynamic parameters of Cu(II) ions removal by apricot stones (AS) waste.

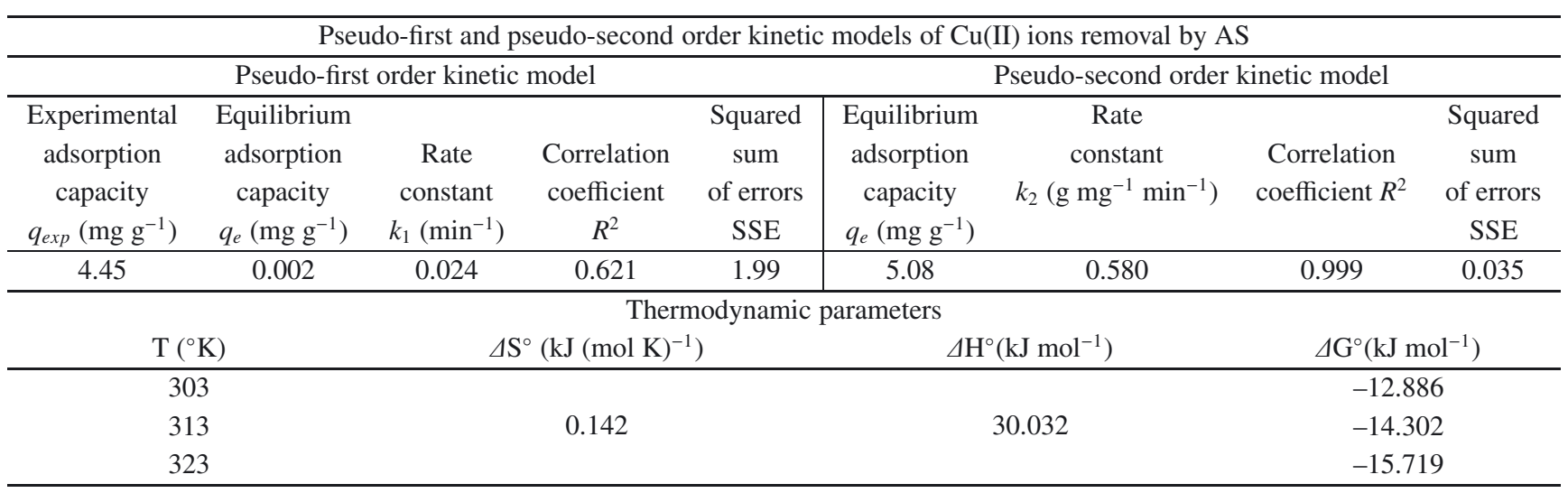

The Freundlich adsorption isotherm is an indication of the surface heterogeneity of biosorbent [45].

$$
q=K_{F} C^{\frac{1}{n}}
$$

where $q\left(\mathrm{mg} \mathrm{g}^{-1}\right)$ is the amount of metal ions adsorbed per mass of adsorbent, $C\left(\mathrm{mg} \mathrm{L}^{-1}\right)$ is the equilibrium concentration, $n$ is the Freundlich constants related to adsorption capacity, and $K_{F}$ is the adsorption coefficient. Values for $n$ less than 1 represent favourable adsorption conditions [52].

The obtained Langmuir correlation coefficient and constant were: $\mathrm{R}^{2}=0.978, q_{m}=4.934 \mathrm{mg} \mathrm{g}^{-1}, K_{L}=0.319 \mathrm{~L} \mathrm{~g}^{-1}$. The $R_{L}$ values were found between 0.057 and 0.380 , indicating that the process of biosorption of $\mathrm{Cu}(\mathrm{II})$ onto $\mathrm{AS}$ was favourable. The obtained Freundlich model correlation coefficient and constant were: $R^{2}=0.792, n=4.9 \mathrm{~g} \mathrm{~L}^{-1}$, $K_{F}=1.965 \mathrm{mg} \mathrm{g}^{-1}$.

According to the correlation coefficient $\left(R^{2}\right)$ as a criterion for good fitness of the system, Langmuir adsorption model expressed a better fit with our experimental data than Freundlich model, what means that the surface of this biosorbent is homogenous.

\subsection{Kinetic study}

Two kinetic models were applied to the experimental data to evaluate the kinetics studies: pseudo-first-order model or Lagergren model [53] and pseudo-second-order model or HoMcKay model [54]. These models are based on the assumption that the rate of sorption is proportional to the number of free sites on the surface of the sorbent [55]. The pseudo-first-order model can be presented in linear form:

$$
\log \left(q_{e}-q_{t}\right)=\log q_{e}-\frac{k_{1}}{2.303} t
$$

where $q_{e}$ is the amount of metal ion adsorbed at equilibrium $\left(\mathrm{mg} \mathrm{g}^{-1}\right), q_{t}$ is amount of metal absorbed at any time $\left(\mathrm{mg} \mathrm{g}^{-1}\right)$ and $k_{1}$ is the rate constants of pseudo-first order adsorption $\left(\mathrm{min}^{-1}\right)$. The values of $k_{1}$ and $q_{e}$ were determine from the plot of $\log \left(q_{e}-q_{t}\right)$ against $t$ and are presented in table III. The pseudo-second-order equation is:

$$
\frac{d q_{t}}{d t}=k_{2}\left(q_{e}-q_{t}\right)^{2}
$$

where $k_{2}$ is the rate constant of pseudo-second-order adsorption $\left(\mathrm{g} \mathrm{mg}^{-1} \mathrm{~min}^{-1}\right)$. Linear form of Equation 9 can be expressed through:

$$
\frac{t}{q_{t}}=\frac{t}{q_{e}}+\frac{1}{q_{e}^{2} k_{2}}
$$

The values of $k_{2}$ and $q_{e}$ were calculated from the slope and intercept of the plot (table III). It was found that the results were better fitted to the pseudo-second-order model with high correlation coefficient $\left(R^{2}>0.999\right)$. The calculated value $q_{e}$ and experimental value $q_{\text {exp }}$ were in agreement, which means that the biosorption of $\mathrm{Cu}$ (II) ions onto AS follows the pseudosecond-order model. It was observed in the literature that most of the biosorption process follows the pseudo-second-order model $[56,57]$.

\subsection{Biosorption thermodynamics}

In order to evaluate the nature of biosorption process of $\mathrm{Cu}$ (II) onto AS, thermodynamics parameters (Gibbs free energy change $-\Delta G^{\circ}$, enthalpy change $-\Delta H^{\circ}$, entropy change - $\Delta S^{\circ}$ ) were calculated from equation:

$$
\Delta G^{\circ}=-R T \ln K_{D}
$$

where $\Delta G^{\circ}$ is the change in free energy $\left(\mathrm{kJ} \mathrm{mol}^{-1}\right), \mathrm{R}$ is the universal gas constant $\left(8.314 \times 10^{-3} \mathrm{~kJ} \mathrm{~mol}^{-1} \mathrm{~K}^{-1}\right)$, T is temperature $(\mathrm{K})$ and $K_{D}\left(q_{e} / C_{e}\right)$ is the distribution coefficient. The values of $\Delta H^{\circ}$ and $\Delta S^{\circ}$ were calculated from the slope and intercept of the plot $\ln K_{D}$ versus $1 / T$ (table III).

Negative values of $\Delta G^{\circ}$ indicate the spontaneous nature of the process of biosorption. Decreasing values of $\Delta G^{\circ}$ with increasing temperature indicate that the adsorption process is more favourable at higher temperatures [58]. The positive values of $\Delta S^{\circ}$ reflect the affinity of the adsorbent towards the adsorbate species [58]. The value of $\Delta H^{\circ}$ was positive, indicating 
Table IV. Comparison of maxima adsorption capacities of $\mathrm{Cu}(\mathrm{II})$ ions on different ligno-cellulosic biosorbents.

\begin{tabular}{lcccc}
\hline Agricultural wastes & $\begin{array}{c}\text { Adsorption } \\
\text { capacity } \\
\left(\mathrm{mg} \mathrm{g}^{-1}\right)\end{array}$ & $S_{S R}{ }^{a}$ & $S_{S E}{ }^{b}$ & References \\
\hline Barley straw & 4.64 & & & {$[5]$} \\
Grape stalks & 10.10 & 0.028 & - & {$[14]$} \\
Banana peel & 4.75 & & & {$[15]$} \\
Orange peel & 3.65 & & & {$[15]$} \\
Olive stone & 2.02 & 1.143 & - & {$[49]$} \\
Corn cob & 3.40 & & & {$[60]$} \\
Apricot stone & 4.45 & & 0.035 & This work \\
\hline
\end{tabular}

${ }^{\text {a }}$ SSR: sum square of residuals; ${ }^{\text {b }}$ SSR: squared sum of errors.

the endothermic nature of the biosorption process. In addition, the magnitude of $\Delta H^{\circ}$ can be very useful in analysis of the sorption type. During physical adsorption evolved heat was of the same order of magnitude as the heats of condensation, i.e., $2.1-20.9 \mathrm{~kJ} \mathrm{~mol}^{-1}$, while during the chemisorption the heats falled into a range of $80-200 \mathrm{~kJ} \mathrm{~mol}^{-1}$. Adsorption of most heavy metal ions by different low cost adsorbents can be attributed to a physico-chemical adsorption process rather than a pure physical or chemical adsorption process [58]. AS waste among other similar low cost adsorbents fall into this group.

\subsection{Desorption study}

Desorption studies are useful to investigate the possibility of recycling the biosorbents and recovery of the metal. In order to determine the percentage of $\mathrm{Cu}(\mathrm{II})$ recovery from $\mathrm{AS}$, biomass were treated with different concentration of $\mathrm{HCl}$ solution. It was found that desorption efficiency was $92.96,92.23$ and $92.19 \%$ for $0.1 \mathrm{~mol} \mathrm{~L}^{-1}, 0.5 \mathrm{~mol} \mathrm{~L}^{-1}$ and $1 \mathrm{~mol} \mathrm{~L}^{-1} \mathrm{HCl}$, respectively. The desorption study for AS showed that $\mathrm{HCl}$ solution recovered almost all the adsorbed $\mathrm{Cu}(\mathrm{II})$, which is in accordance with a recent investigation [32].

Another series of sorption and desorption experiments were carried out in four more cycles using the same biosorbent. Recovery efficiency slowly decreased from $92.96 \%$ (I), $89.90 \%$ (II), $87.50 \%$ (III), 86.25 (IV) to $84.39 \%$ (V) as the number of cycles increased. It can be concluded that recovery of $\mathrm{Cu}$ (II) remained at high level in all cycles.

\subsection{Comparison of different biosorbents for $\mathrm{Cu}$ (II) adsorption}

The differences between biosorption capacities of various biosorbents (table IV) were mainly due to the type, surface structure, morphology and the type of functional groups present in the biosorbent [59]. The results from the present study are compatible with similar biosorbents by their potential for copper removal from aqueous solution.

\section{Conclusion}

This study was focused on the usage of apricot stone (AS) waste without any pre-treatment (removal of seeds was not included) in order to get low cost biosorbent. Investigations showed that the process of copper biosorption is highly dependent on the $\mathrm{pH}$ of the metal solution, the amount of biomass, contact time and its initial concentration. The process optimal parameters are: $\mathrm{pH} 5.0$, biomass concentration of $6 \mathrm{~g} \mathrm{~L}^{-1}$, contact time of $120 \mathrm{~min}$ and initial $\mathrm{Cu}(\mathrm{II})$ ion concentration $60 \mathrm{mg} \mathrm{L}^{-1}$. The involvement of ion-exchange mechanism during the biosorption process was confirmed by results from EDX and by obtaining $\mathrm{R}_{\mathrm{b} / \mathrm{r}}$ which was close to 1 . FTIR analysis showed that active groups from fatty acids and lignin are available to adsorb $\mathrm{Cu}$ (II) ions. It also confirmed a synergetic behaviour of shells and seeds in AS blend. The kinetic studies have shown that equilibrium was reached in 10 min contact time and the biosorption data fits well to the pseudo-secondorder kinetic model. The obtained experimental data followed the Langmuir model. According to thermodynamic study, the biosorption process is feasible, spontaneous and endothermic in nature.

Overall, the preliminary study of biosorption with AS waste has shown that this material can successfully and rapidly remove dissolved $\mathrm{Cu}$ (II) ions from dilute solutions and should be further examined and considered as a cheaper alternative to commercial filters.

Acknowledgements. The authors are grateful to the Serbian Ministry of Science and Technological Development for the financial support of this investigation included in the project TR 31003 project cycles 2011-2015.

\section{References}

[1] Van Dyk J.S., Gama R., Morrison D., Swart S., Pletschke B.I., Food processing waste: Problems, current management and prospects for utilisation of the lignocellulose component through enzyme synergistic degradation, Renew Sust. Energ. Rev. 26 (2013) 521-531.

[2] Sousa F.W., Oliveira A.G., Ribeiro J.P., Rosa M.F., Keukeleire D., Nascimento, R.F, Green coconut shell applied as adsorbent for removal of toxic metal ions used fixed-bed column technology, J. Environ. Manage. 91 (2010) 1634-1640.

[3] Velazqez-Jiminez L.H., Pavlick A., Rangel-Mendez J.R., Chemical characterization of raw and treated agave bagasse and its potential as adsorbent of metal cations from water, Ind. Crop Prod. 43 (2013) 200-206.

[4] Šćiban M., Klašnja M., Škrbić B., Adsorption of copper ions from water by modified agricultural by-products, Desalination 229 (2008) 170-180.

[5] Pehlivan E., Altun T., Parlayici S., Modified barley straw as a potential biosorbent for removal of copper ions from aqueous solution, Food Chem. 135 (2012) 2229-2234.

[6] Rashed M.N., Fruit stones from industrial waste for the removal of lead ions from polluted water, Environ. Monit. Assess. 119 (2006) 31-41.

[7] Leyva-Ramos R., Landin-Rodriguez L.E., Leyva-Ramos S., Medellin-Castillo N.A., Modification of corncob with citric acid to enhance its capacity for adsorbing cadmium(II) from water solution, Chem. Eng. J. 180 (2012) 113-120. 
[8] Alslaibi T.M., Abustan I., Ahmad A.M., Foul A.A., Comparison of activated carbon prepared from olive stones by microwave and conventional heating for iron (II), lead (II), and copper (II) removal from synthetic wastewater, Environ. Prog. Sustain. Energy. 33 (4) (2013) 1074-1085.

[9] Kobya M., Demirbas E., Senturk E., Ince M., Adsorption of heavy metal ions from aqueous solutions by activated carbon prepared from apricot stone, Bioresour. Technol. 96 (2005) 1518-1521.

[10] Gautam R.K., Mudhoo A., Lofrano G., Chattopadhyaya M.C., Biomass-derived biosorbents for metal ions sequestration: Adsorbent modification and activation methods and adsorbent regeneration, J. Environ. Chem. Eng. 2 (2014) 239-259.

[11] Alslaibi T.M., Abustan I., Ahmad A.M., Foul A.A., A review: Production of activated carbon from agricultural byproducts via conventional and microwave heating, J. Chem. Technol Biotechnol. 88 (2013) 1183-1190.

[12] Alslaibi T.M., Abustan I., Ahmad A.M., Foul A.A., Heavy metals removal from wastewater using agricultural wastes as adsorbents: a review, IJCEE 5 (2014) 7-10.

[13] Alslaibi T.M., Abustan I., Ahmad A.M., Foul A.A., Review: Comparison of agricultural by-products activated carbon production methods using surface area response, CJASR 2 (2013) $18-27$.

[14] Villaescusa I., Fiol N., Martinez M., Miralles N., Pocj J., Serarols J., Removal of copper and nickel ions from aqueous solution by grape stalks wastes, Water Res. 38 (2004) 992-1002.

[15] Annadurai A., Juang R.S., Lee D.J., Adsorption of heavy metals from water using banana and orange peels, Water Sci. Technol. 47 (2002) 185-190.

[16] Lee S.H., Shon J.S., Chung H.S., Lee M.Y., Jang J.W., Effect of chemical modification of charboxyl groups in apple residues on metal ion binding, Kor. J. Chem. Eng. 16 (1999) 576-580.

[17] Lopičić Z., Milojković J., Šoštarić T., Petrović M., Mihajlović M., Lačnjevac Č., Stojanović M., Influence of $\mathrm{pH}$ value on $\mathrm{Cu}$ (II) biosorption by lignocellulose peach shell waste material, Hem. Ind. 67 (2013) 1007-1015.

[18] Torab-Mostaedi M., Asadollahzadeh M., Hemmati A., Khosravi A., Equilibrium, kinetic and thermodynamic studies for biosorption of cadmium and nickel on grapefruit peel, J. Taiwan Ins. Chem. Eng. 44 (2013) 295-302.

[19] El-Ashtoukhy E-S.Z., Amin N.K., Abdelwahab O., Removal of lead (II) and copper (II) from aqueous solution using pomegranate peel as a new adsorbent, Desalination 223 (2008) 162-173.

[20] Schiewer S., Patil S.B., Modeling the effect of pH on biosorption of heavy metals by citrus peels, J. Hazard. Mater. 157 (2008) 8-17.

[21] Statistical office of the Republic of Serbia (2014) http://webrzs. stat.gov.rs/WebSite/.

[22] Tsibranska I., Hristova E., Modelling of heavy metal adsorption into activated carbon from apricot stones in fluidized bed, Chem. Eng. Process: Process Intensification 49 (2010) 1122-1127.

[23] Özçimen D., Adsorption of copper(II) ions onto hazelnut shell and apricot stone activated carbons, Adsorpt Sci Technol 28 (2010) 327-340.

[24] Kazemipour M., Ansari M., Tajrobehkar S., Majdzadeh M., Kermani H.R., Removal of lead, cadmium, zink and copper from industrial wastewater by carbon developed from walnut, hazelnut, almond, pistachio shell and apricot stone, J Hazard Mater 150 (2008) 322-327.
[25] Yildiz F., New technologies in apricot processing. 3 J. Standard, Apricot Special Issue, Ankara, (1994) 67-69.

[26] Femenia A., Rossello C., Mulet A., Canellas J., Chemical Composition of Bitter and Sweet Apricot Kernels, J. Agric. Food Chem. 43 (1995) 356-361.

[27] Brunauer S., Emmett P.H., Teller E. Adsorption of gases in multimolecular layers, J. Am. Chem. Soc. 60 (1938) 309-319.

[28] Beauchemin A.K., Using ADF and ND in dairy cattle diet formulation-a western Canadian perspective, Anim. Feed Sci. Tech. 58 (1996) 101-111.

[29] Milonjić S.K., Ruvarac A.LJ., The heat of immersion of natural magnetite in aqueous solutions, Thermochim. Acta. 2 (1975) 261-266.

[30] Milojković J.V., Mihajlović M.L., Stojanović M.D., Lopičić Z.R., Petrović M.S., Šoštarić T.D., Ristić M.D., Pb(II) removal from aqueous solution by Myriophyllum spicatum and its compost: equilibrium, kinetic and thermodynamic study, J. Chem. Technol. Biotechnol. 89 (2014) 662-670.

[31] Leyva-Ramos R., Bernal-Jacome L.A., Acosta-Rodriguez I., Adsorption of cadmium(II) from aqueous solution on natural and oxidized corncob, Sep. Purif. Technol. 45 (2005) 41-49.

[32] Alslaibi T.M., Abustan I., Ahmad A.M., Foul A.A., Microwave irradiated and thermally heated olive stone activated carbon for nickel adsorption from synthetic wastewater: a comparative study, AlChE J. 60 (2014) 237-255.

[33] Iqbal M., Saeed A., Zafar S.I., FTIR spectrophotometry, kinetics and adsorption isotherms modeling, ion exchange, and EDX analysis for understanding the mechanism of $\mathrm{Cd}^{2+}$ and $\mathrm{Pb}^{2+}$ removal by mango peel waste, J. Hazard. Mater. 164 (2009) 161-171.

[34] Laurichesse S., Huillet C., Avérous L., Original polyols based on organosolv lignin and fatty acids: new bio-based building blocks for segmented polyurethane synthesis, Green Chem. 16 (2014) 3958-3970.

[35] Bilba K., Arsene M.A., Quensanga A., Study of banana and coconut fibres- botanical composition, thermal degradation and textural observations, Bioresour. Technol. 98 (2007) 58-68.

[36] Pehlivan E., Altun T., Cetin S., Iqbal B.M., Lead sorption by waste biomass of hazelnut and almond shell, J. Hazard. Mater. 167 (2009) 1203-1208.

[37] Bodirlau R., Teaca C.A., Fourier transform infrared spectroscopy and thermal analysis of lignocellulose fillers treated with organic anhydride, Rom. J. Phys. 54 (2009) 93-104.

[38] Faix O., Classification of lignins from different botanical origins by FT-IR Spectroscopy, Holzforschung. 45 (1991) 21-27.

[39] Martinez M., Miralles N., Hidalgo S., Fiol N., Villaescusa I., Poch J., Removal of lead(II) and cadmium(II) from aqueous solutions using grape stalk waste, J. Hazard. Mater. 133 (2006) 203-211.

[40] Poletto M., Pistor V., Zattera A.J., Structural Characteristics and Thermal Properties of Native Cellulose, in: Van de Ven T., GodboutL. (Eds) Cellulose - Fundamental Aspects, In Tech, chap. 2, 2013.

[41] Han R., Zhang L., Song C., Zhang M., Zhu H., Zhang J.L., Characterization of modified wheat straw, kinetic and equilibrium study about copper ion and methylene blue adsorption in batch mode, Carbohydr. Polym. 79 (2010) 1140-1149.

[42] Carmen G.B., Dominique B., Richard J.A.G., van Dam J.E.G., Characterisation of structure-dependent functional properties of lignin with infrared spectroscopy, Ind. Crops Prod. 20 (2004) 205-218. 
[43] Alslaibia T.M., Abustan I., Ahmad M.A., Foulc A.A., Kinetics and equilibrium adsorption of iron (II), lead (II), and copper (II) onto activated carbon prepared from olive stone waste, Desalination Water Treat. 52 (2014) 7887-7897.

[44] Božić D., Stanković V., Gorgievski M., Bogdanović G., Kovačević R. Adsorption of heavy metal ions by sawdust of deciduous trees, J. Hazard. Mater. 171 (2009) 684-692.

[45] Wang J., Chen C., Biosorbents for heavy metals removal and their future. Biotech. Adv. 27 (2009) 195-226.

[46] Alslaibi T.M., Abustan I., Ahmad M.A., Foul A.A., Cadmium removal from aqueous solution using microwaved olive stone activated carbon, J. Environ. Chem. Eng. 3 (2013) 589-599.

[47] Fiol N., Villaescusa I., Determination of sorbent point zero charge: usefulness in sorption studies, Environ. Chem. Lett. 7 (2009) 79-84.

[48] Nadeem R., Hanif M.A., Shaheen F., Perveen S., Zafar M.N., Iqbal T., Physical and chemical modification of distillery sludge for $\mathrm{Pb}(\mathrm{II})$ biosorption, J. Hazard. Mater. 150 (2008) 335-342.

[49] Fiol N., Villaescusa I., Martinez M., Miralles N., Poch J., Serarols J., Sorption of $\mathrm{Pb}(\mathrm{II}), \mathrm{Ni}(\mathrm{II}), \mathrm{Cu}$ (II) and $\mathrm{Cd}(\mathrm{II})$ from aqueous solution by olive stone waste, Sep. Purif. Technol. 50 (2006) 132-140.

[50] Taty-Costodes V.C., Fauduet H., Porte C., Delacroix A., Removal of $\mathrm{Cd}(\mathrm{II})$ and $\mathrm{Pb}(\mathrm{II})$ ions, from aqueous solutions, by adsorption onto sawdust of Pinus sylvestris, J. Hazard. Mater. B 105 (2003) 121-142.

[51] Vaghetti J.C.P., Lima E.C., Royer B., da Cunha B.M., Cardoso N.F., Brasil J.L., Dias S.L.P., Pecan nutshell as biosorbent to remove $\mathrm{Cu}(\mathrm{II}), \mathrm{Mn}(\mathrm{II})$ and $\mathrm{Pb}(\mathrm{II})$ from aqueous solution, J. Hazard. Mater. 162 (2009) 270-280.
[52] Hameed B.H., Equilibrium and kinetic studies of methyl violet sorption by agricultural waste, J. Hazard. Mater. 154 (2008) 204-212.

[53] Lagergren S., About the theory of so called adsorption of solute substances. Kungliga Sevenska Vetenskapas akademiens Handlingar. 24 (1898) 1-39.

[54] Ho Y.S., McKay G. Pseudo-second order model for sorption processes. Process Biochem. 34 (1999) 451-465.

[55] Michalak I., Chojnacka K., Witek-Krowiak A., State of the art for the biosorption process - a review, Appl. Biochem. Biotechnol. 170 (2013) 1389-1416.

[56] Munagapati V.S., Yarramuthi V., Nadavala S.K., Alla S.R., Abburi K., Biosorption of $\mathrm{Cu}(\mathrm{II}), \mathrm{Cd}(\mathrm{II})$ and $\mathrm{Pb}(\mathrm{II})$ by Acacia leucocephala bark powder: kinetics, equilibrium and thermodynamics, Chem. Eng. J. 157 (2010) 357-365.

[57] Sfaksi Z., Azzouz N., Abdelwahab A., Removal of Cr(VI) from water by cork waste. Arab J. Chem., Special Issue: Environmental Chemistry 7(2014) 37-42.

[58] Saha P., Chowdhury S., Insight into adsorption thermodynamics, in: Tadash M. (Ed.), Thermodynamics chap. 16, In Tech, 2011.

[59] Yuvaraja G., Krishnaiah N., Subbaiah M.V.,Krishnaiah A., Biosorption of $\mathrm{Pb}$ (II) from aqueous solution by Solanum melongena leaf powder as a low-cost biosorbent prepared from agricultural waste, Colloid. Surface B 114 (2014) 75-81

[60] Petrović M.S., Šoštarić T.D., Pezo L.L., Stanković S.M., Lačnjevac Č.M., Milojković J.V., Stojanović M.D., Usefulness of ANN-based model for copper removal from aqueous solutions using agro industrial waste materials, CICEQ (2014).

Cite this article as: Tatjana Šoštarić, Marija Petrović, Jelena Milojković, Časlav Lačnjevac, Aleksandar Ćosović, Marija Stanojević, Mirjana Stojanović. Application of apricot stone waste from fruit processing industry in environmental cleanup: copper biosorption study. Fruits 70 (2015) 271-280. 